Please do not remove this page

RMIT

UNIVERSITY

\title{
From access to success: an integrated approach to quality higher education informed by social inclusion theory and practice
}

Gidley, Jennifer; Hampson, Gary; Wheeler, Leone; Bereded-Samuel, E

https://researchrepository.rmit.edu.au/esploro/outputs/9921861872501341/filesAndLinks?institution=61RMIT_INST\&index=null

Gidley, J., Hampson, G., Wheeler, L., \& Bereded-Samuel, E. (2010). From access to success: an integrated approach to quality higher education informed by social inclusion theory and practice. Higher Education Policy, 23(1), 123-147. https://doi.org/10.1057/hep.2009.24

Document Version: Accepted Manuscript

Published Version: https://doi.org/10.1057/hep.2009.24

Repository homepage: https://researchrepository.rmit.edu.au

(C) 2010 International Association of Universities

Downloaded On 2023/04/27 01:06:49 +1000 


\title{
From Access to Success: An Integrated Approach to Quality Higher Education informed by Social Inclusion Theory and Practice
}

\author{
Jennifer M. Gidley ${ }^{1}$, Gary P. Hampson, Leone Wheeler \\ RMIT University, Melbourne, Australia \\ Elleni Bereded-Samuel \\ Victoria University, Melbourne, Australia
}

\begin{abstract}
Equitable access, success and quality in higher education are examined from a variety of ideological perspectives. Quality is positioned as a complex generic concept while access and success are identified as key concepts in the social inclusion domain, supplemented by the concept of participation. The topic is approached through an integrative analysis of the theory and practice literature on social inclusion in higher education. After contextualising current higher education within economic globalisation, the notion of quality is uncoupled from the necessity of a neoliberal framing allowing broader interpretations arising from more inclusive ideologies. Access, participation and success are shown to represent degrees of social inclusion underpinned by a nested spectrum of ideologies - neoliberalism, social justice and human potential respectively — with human potential ideology offering the most embracing perspective. Australian higher education is foregrounded, yet contextualised within European historical precedents and contemporary global issues.
\end{abstract}

Keywords: access, equity, empowerment, engagement, integration, participation, social inclusion, success 


\section{Introduction}

This essay responds to the question: "Are equitable access, success and quality three essential ingredients or three mutually exclusive concepts for higher education development?" At first glance it appears that the three concepts - equitable access, success and quality - are being regarded as conceptual peers that can be either in harmony with each other or in conflict with each other. A deeper analysis suggests that interpretations of the terms "equitable access" "success" and "quality" and the relationships among them are complex and multiperspectival and can be framed differently in various contexts depending on the underlying ideology of the discourse.

From one perspective, quality in higher education is equated with success in globally competitive league tables and other performance indicators. From this perspective the idea of increasing equitable access to higher education may be seen as competition for scarce funding and thus incompatible. In this view there is competition between social inclusion as access and quality as success in performance indicators.

From another perspective - the one we take in this paper-the terms equitable access and success are intimately linked with the notion of social inclusion in higher education. While access is commonly thought of as being synonymous with social inclusion we suggest that it is only the first step. We propose that with the addition of a third concept, participation, the terms access, participation and success can be seen to reflect "degrees of social inclusion." In this view access, participation and success are ordered according to a spectrum of ideologiesneoliberalism, social justice and human potential respectively — by way of a nested structure with human potential ideology offering the most embracing perspective.

The topic is approached by undertaking an integrative analysis of the literature on social inclusion in higher education, with respect to both theory and practice. In our integrative theoretical approach, instead of quality being in competition with social inclusion, we bring them into cooperation with each other. In this approach quality in higher education can also be viewed along the same spectrum of ideologies. The focus is primarily on Australian higher education with some reference to European higher education literature.

Firstly, the essay provides a contextual background on the implications of globalization for higher education, including the perceived conflict between notions of "access" and "quality."

Secondly, it constructs a broad theoretical framework regarding social inclusion. This involves the identification of areas and degrees of inclusion. Degrees of social inclusion are shown to reflect a spectrum of ideologies, which in turn influence notions of quality in higher education. Finally, an overview of social inclusion interventions is offered, which parallels the different theoretical approaches to inclusion. In this integrative model potentially rival ideologies make iterative contributions to a more balanced social inclusion policy. This approach integrates interventions that increase access, participation and success, pointing to a more comprehensive view of quality in higher education.

In a special issue on "Social Inclusion" in the Policy Futures in Education (2003) journal the editor made the point that,

A key barrier to understanding arises from the fragmentation of policy in relation to different arenas of inclusion/exclusion... Joined-up working has been a much-used cliché which has not been accompanied by connected thinking about the different groups who are at risk of exclusion. (Allan, 2003, Editorial, Para. 1) [italics in original] 
This paper uses integrative - or joined-up — thinking to offer some future policy directions. This is in line with Ernst Boyer's - often overlooked - scholarship of integration. ${ }^{2}$ It supports the kind of " "multi-pronged' strategies for tackling social inclusion, which consider multiple dimensions of social exclusion" (Allan, 2003) and multiple theories and ideologies. Further, by identifying the key ideologies playing out in the debate, it becomes evident why concepts such as equitable access, success and quality may be seen as "mutually exclusive concepts." On the other hand, the nested model presented here demonstrates how such concepts are also "essential ingredients in higher education." In the latter view a developmental progression of policy values may be observed from mere "access" through "participation and engagement" to "success through empowerment", providing differentiated but coherent foundations for quality higher education development.

\section{Globalisation of Higher Education}

As the politico-economic processes of globalisation increasingly impact on socio-cultural spheres, the higher education sector in the $21^{\text {st }}$ century is faced with new and more complex challenges across the globe. The tensions between global, national and regional/local interests found in other discourses are spilling over into the higher education literature.

By the 1990s a subtle shift had taken place in Europe by which the previous "national and cultural role" of higher education was being eclipsed by "the economic rationale" (Huisman \& Van der Wende, 2004). Jeroen Huisman notes that in spite of initial resistance and critique from the higher education sector, the economic rationale was intensified by both globalisation and the rise of information and communication technologies. He argued that "this trend spurred international competition" within higher education (Huisman \& Van der Wende, 2004, p. 350). This issue of global competitiveness - so central to the functioning of neoliberal economic markets - has penetrated the higher education sector. Indeed,

This international competitive stance not only relates to the export of higher education, but also to issues of quality. For instance, the Austrian government has established an accreditation mechanism that may be interpreted as a shift towards international competition (instead of cooperation). (Huisman \& Van der Wende, 2004, p. 354)

Yet the complexity of our times allows new scope for "cross-border initiative and invention in both knowledge and university strategy" (Marginson, 2007). Such transversing of borders is exemplified by The European Commission Bologna Process, ${ }^{3}$ part of the "European agenda towards converging systems of higher education." In this regard Huisman claims that, "in less than 10 years, harmonisation (although preferably called 'convergence') of higher education structures changed from an undesirable objective to a highly advisable aim." (Huisman \& Van der Wende, 2004, pp. 349-350)

Globalisation has also stimulated mobility (of students, academics and ideas) with the unexpected effect of enabling new insights into the diversity of higher education systems (Lunt, 2008). Both established and newer higher education institutions in the North and the South compete for market share in the knowledge economy to prevent "brain drain" (Huisman \& Van der Wende, 2004), to foster "brain gain", and even to encourage "brain circulation" (Kenway \& 
Fahey, 2009) and global talent flows (Welch \& Zhen, 2008). Marginson notes that student mobililty is asymmetrical whereby "some nations are primarily exporters, others are primarily importers" (Marginson, 2004, p. 202). New discourses have emerged on international education, comparative education and global education. The rise of international, transnational and supranational organisations has furthered the drive to restructure. Educational researchers with an eye to the future provide diverse views on the drivers of change in university transformation (Inayatullah \& Gidley, 2000) and the complex lessons to be learned in education for the future (Morin, 2001). The International Commission on Education for the $21^{\text {st }}$ Century has developed four pillars of education-learning to be, learning to know, learning to do and learning to live together. These are aimed at shifting the educational focus from "the local community to a world society", from "social cohesion to democratic participation" and from "economic growth to human development" (Delors, 1996).

\section{The Tension between Elite Institutions and Mass Higher Education}

There is little contention that in the last few decades we have witnessed a shift in higher education policy, at least in the Anglo-European context, from universities as elite institutions for the few to higher education as a birthright of the many. This shift is well exemplified in the UK higher education policies of the 1990s. Ingrid Lunt summarised the challenges that the UK higher education system faced at the beginning of the Blair government, noting that similar challenges were arising at the time in the HE systems of all developed countries. Lunt claimed that "the shift from an elite to a mass HE system" led to decreases in public funding to universities creating increased financial challenges. She also argued that the higher education sector felt a need to respond competitively because of beliefs in "the link between the economy and the knowledge and skills of the labour force." The result, she claimed was the so-called "high skills economy" and the "commodification of knowledge" (Lunt, 2008, p. 742).

As a counter trend there is evidence in the last few years to suggest the pendulum may be swinging back towards elitism. Some researchers applaud the concept of the Emerging Global Model (EGM) of the elite 21st century research university, claiming that such "top stratum of research universities worldwide" are key to "economic and social development" (Mohrman, Ma, \& Baker, 2008). Mohrman et al. identify eight characteristics of the EGM: global mission, research intensity, new roles for professors, diversified funding, worldwide recruitment, increasing complexity, new relationships with government and industry, and global collaboration with similar institutions (Mohrman, Ma, \& Baker, 2008). However, other researchers raise new questions about the impact of such a concentration of resources on higher education more broadly in Europe and Asia (Deem, Mok, \& Lucas, 2008). OECD Analyst Jaana Puuka reminds us that the "new wider mission of higher education institutions, often characterized as a 'third task' or social obligation, can be best mobilized in the context of regions" (Puuka \& Marmelojo, 2008). This third task is aligned to Boyer's scholarship of application (Boyer, 1990).

Marginson claims that the current "transnational markets in higher education are structured as a segmented hierarchy" reflecting dominance/subordination in three aspects: between "developed" and "developing nations"; between English and non-English language universities; and between "the hegemonic power of the United States in world higher education" and higher education in the rest of the world (Marginson, 2004, p. 218). He goes as far as to claim that "the old equality of opportunity project is now in terminal crisis, and will continue to be undermined 
by heightened status competition, markets, cross-border leakages of people and resources, and global commercialisation" (Marginson, 2004, p. 234).

In the light of these developments must we conclude that the notion of quality in higher education has again been hijacked by elite institutions at the expense of mass education? Or is there a way that quality in higher education may be viewed more systemically, more integrally?

\section{Changing Views of Quality in Higher Education}

What needs to be discussed here is what is meant by (or what is the identity of) quality in higher education. While the emerging discourse on EGMs suggests that quality in higher education is dependent on research and funding concentration and can be measured by league tables and other performance indicators, it needs to be recognised that this view is underpinned by a particular ideology. The idea of EGMs has emerged from a global knowledge economy based on the freemarket neoliberal ideology where individual institutions compete with each other. That this ideology, neoliberalism, is the dominant one - and thus invisible in much of the discourse-will be further discussed below.

The UK provides a good case study of the tension between the elite notion of quality in higher education and the social justice ethic towards greater access to higher education. Lunt refers to this as "the trade-off between excellence and equity" (Lunt, 2008). She notes "the total increase in participation rates masks a considerable variation by social class" (Lunt, 2008) reflecting the paradoxes and tensions even when a government such as that of New Labour attempts to balance the global competitiveness with social inclusiveness and equity. Although Blair's policy rhetoric gave equal weighting to an espoused commitment to "social inclusion and equity", this did not have the significant impact on universities effected by his "enhanced global competitiveness" policy (Lunt, 2008). While the prior conservative agenda led to dramatic increases in access to higher education - an increase of one-third in overall student numbers - by 1997, "this expansion had not succeeded in reducing class inequalities" (Lunt, 2008, p. 742).

Similar observations have been made in Australia: "the effect of interventions based on this liberal position has been to maintain the status quo of power and privilege with exception proving the rule" (Nunan, George, \& McCausland, 2005, p. 252). Marginson claims:

Neo-liberal marketisation raises sharper questions about social inequality in higher education, in two dimensions: equality/inequality of access to opportunity, and equality/inequality of the opportunities themselves. All else being equal, economic markets are associated with greater social inequalities of access in systems mediated by the private capacity to pay, so that access is more steeply stratified on social lines; and with a steeper hierarchy of institutions, so that what is accessed is also increasingly stratified. (Marginson, 2004, p. 234)

This paper questions the default neoliberal idea of quality as a measure of a particular university or a particular nation's competitive edge. It presents two broader notions of quality in higher education which need to be systemically strengthened in the whole domain of higher education globally. From the ideology of justice globalism, which will be further discussed below, global networks of higher education institutions would collaborate rather than compete with each other. ${ }^{4}$ And from the perspective of human potential ideologies, quality in higher education would mean more than global competitiveness or higher levels of access, but would be 
related to human potential and transformation. The following sections will expand these alternative notions of quality.

\section{From Access to Success: Integrative Theorising of Social Inclusion}

\section{Brief History}

Social inclusion is a contested term in both the academic and policy literature with a diversity of definitions available. Rather than bring closure to a "definition" at this early stage, the paper briefly reviews the history of the term, and then considers how it is viewed from three different ideological perspectives.

The term "social inclusion"-currently promoted by the Australian Government-is a relatively new one in Australian higher education policy literature. Social inclusion appears poised to replace terms such as access and equity, which reflected earlier policy iterations in relation to increasing the proportion of disadvantaged groups in higher education. The new social inclusion policy in Australia suggests links to similar policies developed by the Blair government. A key question is: "To what extent does the new term, social inclusion, reflect a shift in policy; or is it merely old policies repackaged?"

The idea of social inclusion can be traced back at least to the $19^{\text {th }}$ century work of German sociologist, Max Weber. The modern use of the counterpart term "social exclusion" emerged in France with an emphasis on the importance to society of social cohesion. The 1970s French notion of les exclus referred to those who were excluded from the social insurance system (Hayes, Gray, \& Edwards, 2008). The concept spread in Europe throughout the 1980s and 90s, culminating in Tony Blair's Social Exclusion Unit, created in 1997. The adoption of similar policy in Australia has been more recent, beginning in South Australia in 2002 and then nationally via the Rudd government's Social Inclusion Board inaugurated in May 2008 (Hayes, Gray, \& Edwards, 2008).

\section{Areas of Inclusion}

Within the policy literature of the current Australian government, the predominant emphasis regarding social inclusion in relation to higher education is on the following groups: disadvantaged geographic areas, indigenous Australians, and those living with homelessness, joblessness, disability, health and/or mental health issues (Gillard, 2008). Taking a more global view the International Association of Universities policy on equitable access, success and quality in higher education includes the following in the under-represented groups "socio-economic status, race, ethnicity, religion, age, [dis]ability or location" (International Association of Universities, 2008). The special issue of Policy Futures in Education included articles on poverty, gender, ethnicity/race, disability, faith/religion and criminality (Allan, 2003).

In the light of the global literature a critique of the Australian social inclusion policy is that it pays insufficient attention to several groups. Firstly, these include those groups pertaining to cultural and linguistic diversity, refugee status and religious diversity (Kelly, 2003). Secondly, it is becoming widely recognised in Australia with its expansive geography and low density 
population that more attention needs to be paid in relation to the inclusion of students living in rural and isolated areas (Ferrari, 2008; Hunt, 2007). Thirdly, there is a growing awareness in Australia of an ageing population yet there is insufficient attention in the policy and other literature about the needs of older Australians to access life-long learning (McIntyre, 2005). Fourthly, there is a serious gap in the social inclusion literature with respect to those people who have been incarcerated. Although many of them also fall into the other identified categories, such as low SES, Indigenous, CALD and mental health challenges, they have special needs that should be identified and researched (Duff, 2003). Finally, although discrimination and exclusion based on gender is addressed in most policies, they are rarely addressed in relation to sexual orientation. An exception is the UK National Child and Mental Health Service Support Service ${ }^{5}$ policy on social inclusion which specifically identified lesbian, gay, bisexual and transgender (LGBT) as a category of concern. It noted that there are a number of factors that "make young LGBT people vulnerable." Although a few studies do address this issue (Rasmussen, 2003; Skelton, 1999) perhaps this group needs to be more explicitly identified in the social inclusion literature.

Another challenge of this discussion regards that within which these policies are seeking to include people. If policies and interventions remain at the level of top down imposition of assumed common values, then it is likely that many of the groups discussed above, even if given access to higher education, may choose not to participate wholeheartedly. Multi-stakeholder dialogues and strategic visioning processes are needed to uncover that which these groups want to participate in. This relates to the underpinning ideologies as discussed below.

\section{Degrees of Inclusion}

Social inclusion can be understood as pertaining to a nested schema regarding degrees of inclusion. The narrowest interpretation pertains to the neoliberal notion of social inclusion as access; a broader interpretation regards the social justice idea of social inclusion as participation or engagement; whilst the widest interpretation involves the human potential lens of social inclusion as success through empowerment (see Figure 1). These will now be discussed in more detail.

\section{A Layered View of Ideologies underlying Social Inclusion Theory}

To demonstrate how these different ideologies frame the issue of social inclusion and higher education, we will discuss each approach giving examples from some of the discourses that arise. We will briefly discuss how social capital theory if not used critically can be an example of neoliberalism; how partnership theory can be used as an example of social justice values; and how futures oriented pedagogies of hope can exemplify human potential values. 
Figure 1: Spectrum of Ideologies Underlying Social Inclusion Theory and Policy

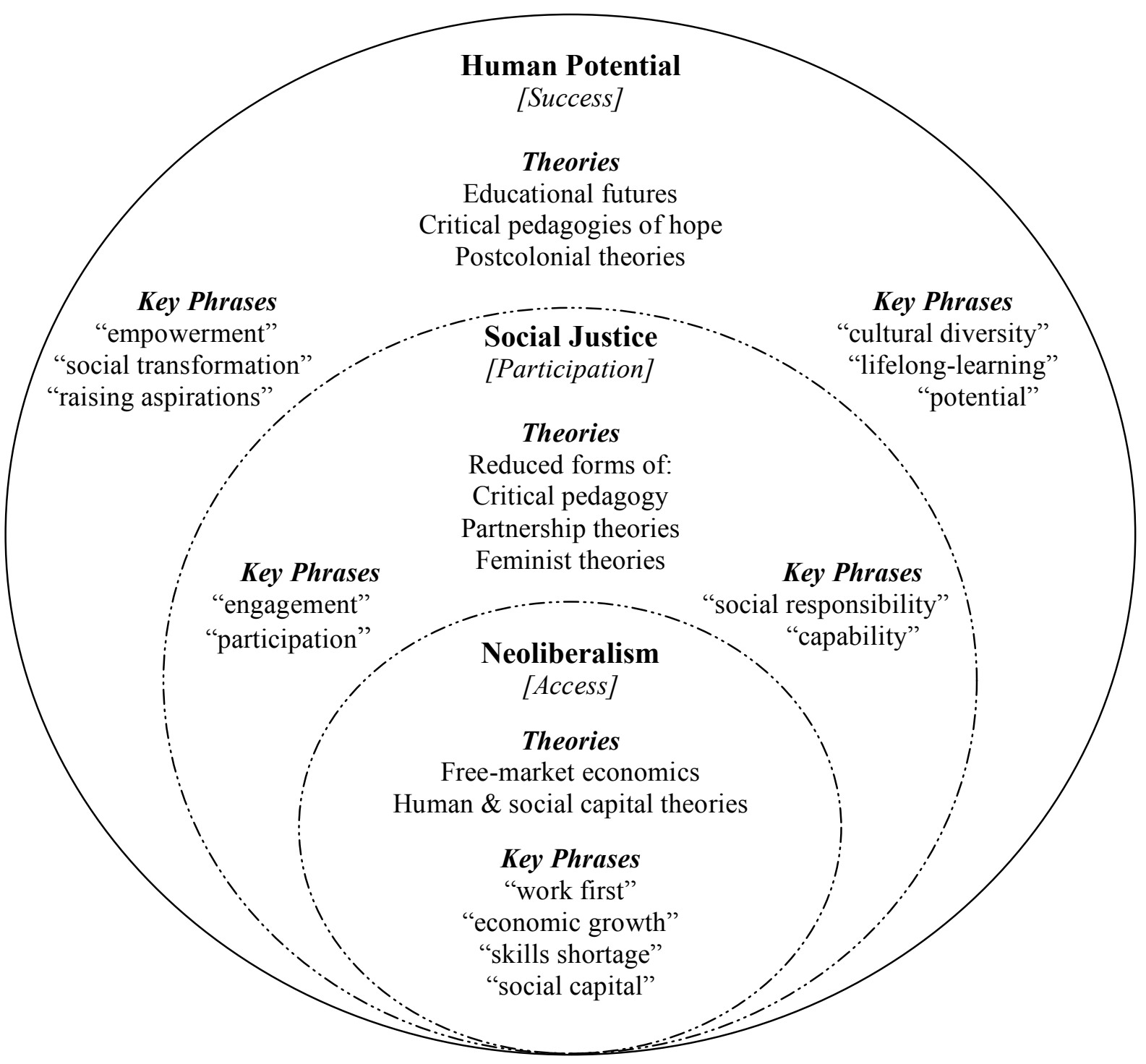

Source: Dr. Jennifer M. Gidley (C) 2009

\section{Access: Neoliberal Ideology}

The narrowest interpretation of social inclusion is linked to the ideology of neoliberalism. From the perspective of neoliberal ${ }^{6}$ ideologies, increasing social inclusion is about investing in human capital and improving the skills shortages for the primary purpose of economic growth as part of a nationalist agenda to build the nation's economy in order to better perform in a competitive global market. In this theory the disadvantaged will eventually be included in global wealth 
distribution through what is called the "trickle down effect." Political scientist, Manfred Steger, who notes that the term "neoliberalism" began to be used in the 1980s, details its central tenets as follows:

The central tenets of neoliberalism include the primacy of economic growth, the importance of free trade to stimulate growth, the unrestricted free market, individual choice, the reduction of government regulation, and the advocacy of an evolutionary model of social development anchored in the Western experience and applicable to the entire world. (Steger, 2005, p. 8-9)

Some researchers argue "the current market-oriented environment of higher education is hostile to the development of inclusive education in universities" (Nunan, George, \& McCausland, 2000, Abstract). To the extent that neoliberal policy considers social inclusion to be important at all, it is related to increasing access to higher education for the primary purpose of increasing the national skills base and improving the economy. Access is about numbers and percentages and does not necessarily reflect student participation or success, nor does it reveal anything about the quality of the education that is accessed. In the neoliberal approach definitions of social inclusion use economic metaphors such as "skills banks", "investing in children" and "social capital."

The notion of social capital is linked with the notion of human capital grounded in neoclassical economics. Researchers from Melbourne University claim that "the primary attraction of the social capital approach is that it allows (or appears to allow) the nonmercantile resources in a community to be treated within a quasi-market framework" (Bexley, Marginson, \& Wheelahan, 2007, p. 10-11). The researchers also noted that the original notion of social capital formulated by Bourdieu "uses social capital explicitly in order to explain the reproduction of social class divisions and inequalities of power", whereas the popularised notion of social capital of Putnam and others "cloud the differences in the potential productivity of social networks" (Bexley, Marginson, \& Wheelahan, 2007, p. 11). Bexley et al. claim that the problem with the latter stance is that those who are disadvantaged by the system can again be held responsible for their lack of social capital. This is an inherently neoliberal idea. In a UK casebased on Putnam's rather than Bordieu's reading of social capital-Bexley et al. report:

The failure to appreciate the obstacles faced by the most socially and economically disadvantaged was matched by a failure to appreciate the comparatively high levels of power held by experienced bureaucrats and business representatives in partnership with community representatives. (Bexley, Marginson, \& Wheelahan, 2007, p. 12)

Another feature of the neoliberal approach to social inclusion is that it works from models of deficiency, somewhat akin to the axiom of mainstream economics pertaining to scarcity of resources. It can also be reductive in the sense of promoting a dominator hierarchy homogenising that which is included. The reduction of social explanation to economic factors is an example of conceptual reductive integration, whilst lifeworld reductive integration would be exemplified both by cultural assimilation and stakeholder dominator hierarchies. The latter, for instance, might involve corporate interests or government attempting to marginalise the interests and agendas of community voices such as those of indigenous, homeless, disabled, gay, youth or elderly groups (or their advocates).

In summary this agenda advocates for a free-market, privatised approach to higher education with a research concentration (and thus funding concentration) in a small number of elite 
institutions whereby small numbers of individuals may excel at the expense of others. The predominance of the neoliberal agenda in the global higher education sector has led to the coining of the term "knowledge capitalism" (Burton-Jones, 2003). Against such corporatisation of higher education critical theorist Henri Giroux takes a strong stance:

The expansion of neo-liberal capitalism globally suggests an especially dangerous turn at the current historical moment, one that threatens both the substance of democracy as fundamental to the most basic freedom and civil liberties, and the very meaning of higher education. (Giroux, 2003, Abstract)

\section{Participation/Engagement: Social Justice Ideology}

A more inclusive interpretation of social inclusion is identified through social justice ideology. From the perspective of social justice ideologies, increasing social inclusion is about human rights, egalitarianism of opportunity, human dignity, and fairness for all. It may or may not be linked to economic interests, but its primary aim is to enable all human beings to participate fully in society with respect for their human dignity. This interpretation of social inclusion foregrounds notions of participation and engagement. The critical pedagogy theories are examples of educational theories grounded in the principles of social justice (Freire, 1970; Giroux, 2003; Kincheloe, Steinberg, \& Hinchey, 1999; Kincheloe, Steinberg, \& Villaverde, 1999) though these critical education theorists also support emancipation, empowerment and human potential as further discussed below.

An important distinction between "access" and "participation" is made by researchers in a study of social inclusion in higher education in the UK. They argue that "access to HE" is merely the starting point, claiming that: "certain groups within society are still significantly underrepresented and disadvantaged at the level of participation" (Tonks \& Farr, 2003, Abstract). The important link between justice theories and participation can be summarised as follows: "There is another more critical set of notions that see inclusivity in educational contexts as concerned with successful participation which generates greater options for all people in education and beyond" (Nunan, George, \& McCausland, 2005, p. 252).

Universities can play a key role in participatory social inclusion via university-community partnerships. While undoubtedly some of the rationale behind the drive for universities to partner with industry is for the purpose of increasing research funding, the trend for universities to partner with communities is less likely to be driven by economic goals. Many of those involved in pioneering university-community partnerships particularly in low SES and rural/regional areas appear to be primarily motivated by social justice concerns and issues of regional and/or community development. Anne Langworthy argues that the need for university-community engagement goes well beyond the economic and is "essential for the sustainability of communities" (Langworthy, 2008, p. 57). A broader contextualisation of the rise of the partnership model today can be found in the research of American cultural historian Riane Eisler and her partnership approach to education (Eisler, 2001).

A review of the literature on effective university-community partnering discusses a number of theories that inform the research on university-community partnership. These include "linkage complexity", "learning theory", "goal setting", "network embeddedness", "participatory action research", "evolutionary theory" and "interpersonal relationships" (Kenworthy-U'Ren \& U'Ren, 2008 , p. 89). The authors discuss definitions, management issues and key themes in universitycommunity partnerships concluding that there is a major shift occurring from the old "ivory- 
tower" concept of a university. This points to what Barbara Holland calls "the engaged campus" which is grounded in notions of university-community engagement (Holland \& Gelman, 1998).

Taking up the notion of engagement in education, Beverley Thompson explores definitions and related theoretical concepts. She notes that the literature on engagement includes such notions as "academic service learning", "authentic learning", "experiential education", and "constructivist teaching" (B. Thompson, 2008, p. 42-43), all involving the notion of some kind of community partnership which facilitate "real-life experience." Thompson investigates many types of engagement and develops a typology of engagement, which she refers to as "the three C's of engagement learning-collaboration, complexity and contract" (B. Thompson, 2008, p. 46). These constructs are discussed in some detail in her paper. She points to the need for engaged partnerships to move from being "reactive" to being "responsive or intentional" (B. Thompson, 2008, p. 48).

The most common critique of a more socially inclusive egalitarian approach to higher education is that it spreads the resource efforts too thin leaving a parochial and dumbed down system which is not globally competitive. Critical apprehension of differences between rhetoric and reality may also be elicited. For example, a discourse that refers to social justice, social responsibility or fair go may nonetheless mask economistic intent regarding merely skills shortages and/or economic growth.

In contrast to reductionist forms of integration promoted by neoliberalism, social justice interpretations of social inclusion comprise complex integrations involving participatory dialogue arising from the full ecology of interests regardless of power. Such participatory complexity is further enhanced within human potential ideologies.

\section{Success through Empowerment: Human Potential Ideology}

Potentially the most inclusive and integrative interpretation of social inclusion is identified as human potential ideology. From this perspective, social inclusion asserts and goes beyond both economic equity/access, and social justice notions of equal rights for all, to maximise the potential of each human being thus supporting broader cultural transformation. Employing models of possibility instead of models of deficiency, human potential approaches take a further step beyond access and participation to encourage the interpretation of social inclusion as empowerment. As stated in the conclusion to IAUs recent policy statement, "Access and participation in higher education are essential for the empowerment of all, especially those often excluded" (International Association of Universities, 2008).

It is worth noting that the Australian government social inclusion policy does make an important linguistic shift from the negative framing of "poverty", "disadvantage", "deprivation" and "exclusion" to the more positive framing of "inclusion." It is to be hoped that this marks the beginning of a directional shift in attitude from "deficit" models to "human potential" models.

Such a perspective foregrounds the notion that all human beings, including those who have been marginalised for whatever reasons, are multi-dimensional beings, who have needs and interests that go well beyond their role in the political economy of a nation. This perspective can be encapsulated in the reframing of social inclusion as "ethical inclusion" in a recent Australian publication: "Broadly, the term [social inclusion] means the empowerment of individuals to participate as fully as possible in society" (Olsson, 2008, p. 6). Jayne Clapton highlights that social inclusion is not just about access and equity but about "the moral imperative of working 
with the complexity of humanity" and having awareness that "education is transformative" (cited in (Olsson, 2008, p. 9)).

Discourses inspiring such perspectives include adult developmental psychology theories that propose higher stages of human reasoning (Commons \& Richards, 2002; Cook-Greuter, 2000; Sinnott, 1998), critical and transformative pedagogies of hope that reverse the focus on disadvantage and deficit and look towards positive development, lifelong and life-wide learning and empowerment (Bassett, 2005; Freire, 1995; Giroux, 2003; Hart, 2001; Kincheloe, Steinberg, \& Hinchey, 1999; Montuori, 1997; Visser, 2000), postcolonial development theories that resist the westernisation and homogenisation of diverse cultures (Jain \& Jain, 2003; Jain, Miller, \& Jain, 2001) and discourses regarding multicultural histories, and positive futures visioning (Gidley, 2001, 2005).

Luke Egan, Jude Butcher and Ken Ralph from the Australian Catholic University claim that levels of engagement are enhanced when "community members are empowered to reconnect with society" (Egan, Butcher, \& Ralph, 2008, p. 34). Clearly this notion of empowerment goes beyond mere access to higher education or even participation. Such an approach hints at levels or degrees of social inclusion.

This progression beyond access and participation has been extended further in the Access and Success $^{7}$ project at Victoria University, Australia (Cherednichenko \& Williams, 2007). A similar project $^{8}$ was announced in the USA aimed at "closing by at least half the gaps in both collegegoing and degree completion that separate low-income and minority students from others." Synchronously, the $13^{\text {th }}$ General Conference of the International Association of Universities in Utrecht, the Netherlands in July 2008, adopted a new policy statement called, Equitable Access, Success and Quality in Higher Education. This policy makes a very clear statement about the relationships among "access", "participation" and "success" stating: "The goal of access policies should be successful participation in higher education, as access without a reasonable chance of success is an empty phrase" (International Association of Universities, 2008).

Egan et al. draw on social psychologist Charles Richard Snyder's hope theory, pointing to the value of Snyder's three dimensions of hope-goals, pathways and agency. They claim that there is a mutually reinforcing cycle when these three dimensions of hope are activated, for example,

When a person's pathways thinking is enhanced, and they become more able to generate effective pathways to their goals, it is likely that they will then become more motivated to follow these routes. Conversely, when a person becomes more motivated to pursue their goals, it is likely that they will thus be more energised to think of workable routes to their goals. (Egan, Butcher, \& Ralph, 2008, p. 35)

A primary benefit that Egan et al. see for linking hope theory with community engagement is that the latter enhances both pathways thinking and agency. Some recent educational futures research has also explored the relationship between youth suicidality and the culture of hopelessness being promoted by western media, and also looks to positive futures visioning as a way of reconstructing hope among young people (Gidley, 2001, 2005). Such empowerment methods are just one of several approaches within the futures education field (Gidley, Bateman, \& Smith, 2004).

A crucial difference between these theories and much of neoliberal theory is that there is no one ideal-e.g. European, or Anglo-American - model of human development. Rather the notion of cultural and individual diversity is embraced whereby individuals are socially included, not so that they "fit in" or "are assimilated into" some pre-existing Westerncentric society or factory 
model of education, but rather that they bring with them the richness of their individual difference - be it gender, culture, age or ability. Indian researcher Ashis Nandy has written extensively on the significance of the categories of knowledge that we live by and the need to make transparent the power that lives in these dominant categories of knowledge (Nandy, 2000). Professor Denise Bradley ponders how a more substantial Indigenous involvement in higher education might look:

Indigenous involvement in higher education is not only about student participation and the employment of Indigenous staff. It is also about what is valued as knowledge in the academy. Indigenous students and staff have unique knowledge and understandings which must be brought into the curriculum for all students and must inform research and scholarship. (Bradley, Noonan, Nugent, \& Scales, 2008, p. 32)

The inclusion - indeed, celebration — of culturally diverse voices in educational curricula and processes is surely a way forward to increase not just equitable access, but engaged participation and empowered success.

\section{A Layered View of Social Inclusion Practice}

A number of social inclusion interventions are identified and situated according to their apparent underpinning ideology: interventions which focus on the economic benefits of social inclusion are generally underpinned by neoliberal economic theory and rely on economic investment; interventions which focus on social justice tend to be grounded in sociology and/or critical social theory and involve social interventions (perhaps in addition to economic investment); interventions which focus on human potential tend to be grounded in positive psychology and pedagogy theories of human development, empowerment and transformation in which the emphasis is less on economic investment and more on psychological and spiritual values of generosity, community and gifting (see Figure 2).

\section{Interventions to Increase Access}

Much government policy, being grounded as it is in neoliberal politico-economic theory, tends to focus on both the economic benefits of improved access and participation and also on the economic costs (albeit framed as investments) of social inclusion interventions. When a new intervention is announced there is always an announcement about how many millions of dollars the intervention will cost the government. This economic framing is so much part of the dominant policy discourse that it goes largely unnoticed.

As indicated in Figure 2, there are numerous interventions that could be introduced to increase the access to higher education of various under-represented groups. There is no question that significant increases in higher education funding targeted at these interventions would increase access to higher education. These can be regarded as important first stepping stones to the more inclusive understandings of social justice and human potential interventions: 
Figure 2: Access, Participation and Success in Social Inclusion Interventions

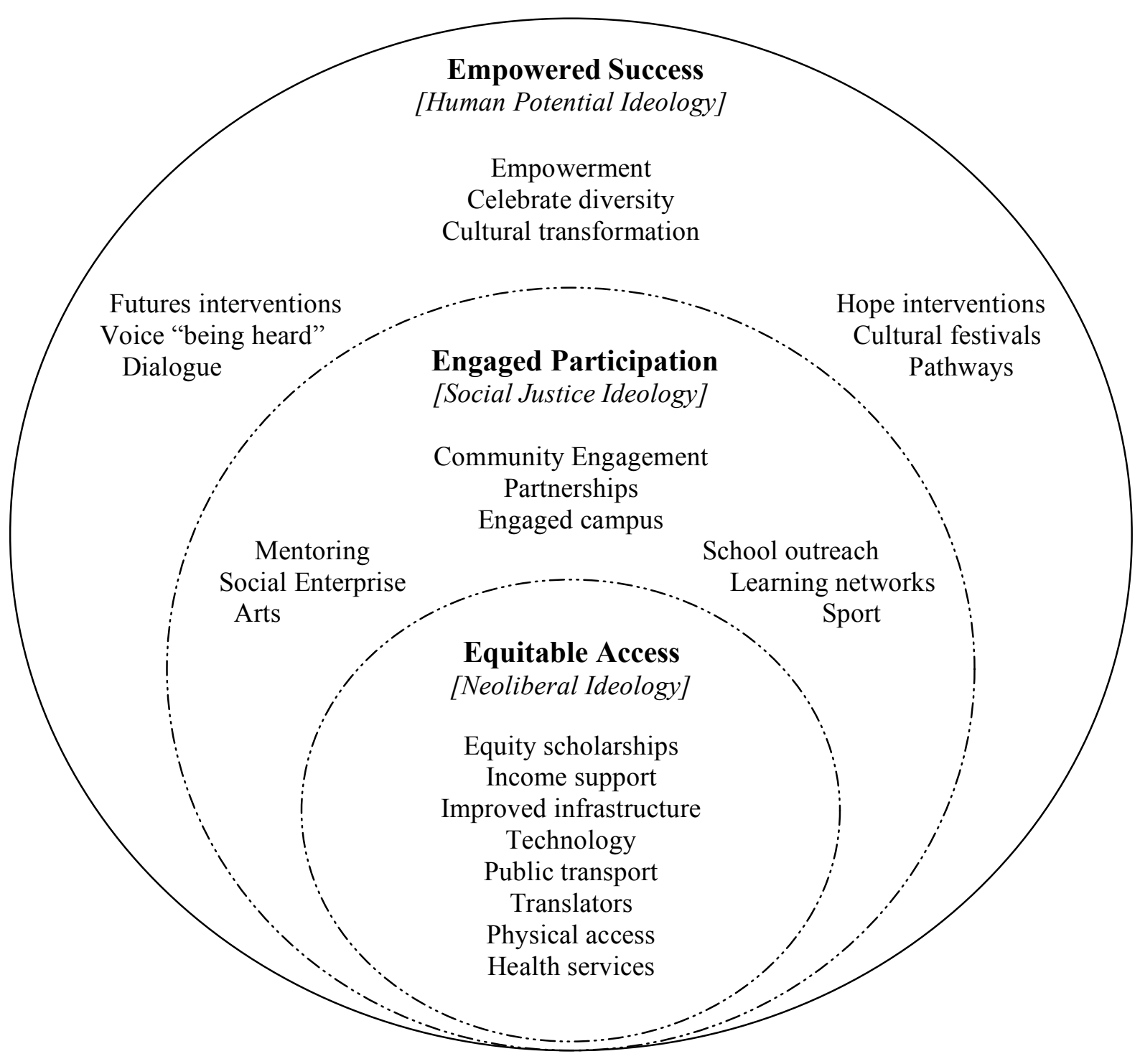

Source: Dr. Jennifer M. Gidley (C) 2009

- more equity scholarships for low SES groups;

○ better income support for low SES students;

- improved regional infrastructures, including better public transport and technology access for rural and isolated and particularly indigenous students;

- physical and architectural modifications for students with disabilities;

- additional teaching assistance and translation assistance for students with learning disabilities or from CALD backgrounds; and

- better counselling and health services for students with psychological and/or physical health challenges. 
While not wanting to give the impression that such interventions are not important, this paper views such interventions as merely the beginning of the social inclusion agenda. As suggested above, access to higher education for under-represented groups is fundamental, but it does not necessarily lead to active participation, engagement, empowerment or success. Nor does it guarantee that quality learning is taking place.

\section{Interventions to Increase Participation/Engagement}

In recent years there seems to have been a gradual increase in the number and range of social justice oriented social inclusion interventions in Australian universities. It is beyond the scope of this paper to make more than brief reference to a few representative examples from the types of interventions listed in Table 2 above.

Partnerships: The notion of partnerships has become almost ubiquitous in social inclusion literature. In October 2008 an entire conference was devoted to Partnerships for Social Inclusion, organised by the University of Melbourne Centre for Public Policy. Many of the examples below were presented as papers at this conference. Victoria University Community Engagement Programs, directed by Elleni Bereded-Samuel, plan, develop and implement strategies to increase the scope of the university's community engagement, especially with culturally and linguistically diverse communities.

Social enterprise: The notion of social enterprise and social entrepreneurship is emerging as a way "to tackle deep-rooted issues in the areas of regeneration, community empowerment, longterm unemployment ... and improving public service delivery" (Robbie, 2008, Abstract).

Mentoring: The value of mentoring for building a sense of community among young people in regional areas has been reported in a study where a Network Partnership Model was used in the Mentoring and Community Building Initiative (coordinated by the Office for Youth) (Broadbent \& Whitehead, 2008). A student peer mentoring program has also been reported to assist new university students from under-represented schools (James, 2008, p. 66).

Learning networks: The role of learning networks is to broker learning and research opportunities in partnerships between universities, schools and other organisations within local communities. RMIT University LearnLinks, directed by Leone Wheeler, was used as a case study to gain insight into the common elements of an operational framework required for a sustainable learning network.

Arts interventions: Several studies focused on how involvement in the arts can enhance access and increase social and cultural inclusion for people with disabilities (Rix, 2003; A. Thompson, 2008, Abstract). Another study reviewed two major research and evaluation reports on the significance of arts in strengthening communities (Grinblat \& Kershaw, 2008, Abstract).

Sport interventions: The role of sport in increasing the social inclusion of newly arrived and refugee young people in Melbourne found that "participants are increasing their social and civic participation within their local communities" (McGill, 2008, Abstract).

School Outreach: School outreach programs can facilitate seamless educational pathways from early childhood, through university and beyond. Examples include: Griffith University Pathways to Prevention (Olsson, 2008); RMIT University Schools Network Access Program (SNAP) (Fels, 2008, p. 6); partnership with the Smith Family's Learning for Life Program; academic assistance in schools; and academic enrichment and university orientation (Universities 
Australia, 2008, pp. 60-61). Special entry programs include: teacher recommendation systems; portfolio entry; bridging courses; and TAFE/VET pathways.

\section{Interventions to Increase Success and Empowerment}

While it may be difficult to accurately discern the difference between the previous and subsequent programs in terms of underlying values, and indeed there is much overlap between the ideologies, theories and approaches, it is a matter of emphasis. The following programs appear to have a stronger focus on success, empowerment and maximising human potential.

Pathways: In a sense many of the interventions discussed in the previous section and this section relate to finding alternative pathways to higher education. However, in the interventions below these pathways are perhaps not so obvious as they may be indirect pathways by way of enabling the person or persons to have their "voices heard," to engage in "dialogue" about their cultural or religious differences, to have "hope," to feel "empowered," or to feel that their cultural values, perhaps as expressed in their cultural festivals, are being honoured.

Voice "being heard": The importance of having "their voices heard" is an Australian government criteria for social inclusion (Gillard, 2008). An Irish study focuses on "the potential to construct new discourses on inclusion to inform partnership institutions which could promote social integration through enabling increased voice for those experiencing exclusion in decision making" (McInerney, 2008, Abstract). A Victorian government initiative involves community networks, assisted by Indigenous Community Engagement Brokers, to give voice to Indigenous Australians through greater participation, engagement and representation (Callaghan \& Moser, 2008).

Dialogue: If we take the notion of voice a little further it enables the process of dialogue to emerge. This can involve intercultural and/or interreligious dialogue (Newman, 2008). The significant role of intercultural dialogue in furthering social inclusion has been emphasised by the co-founder of the Global Dialogue Institute in Philadelphia (Gangadean, 2006).

Futures interventions: The significance of taking a long-term view in planning and social interventions has been stressed for decades by futures researchers. A New Zealand initiative, called Long Term Council Community Plans, mandates local councils to undertake community strategic planning. The project "articulate[s] economic, social, environmental and cultural wellbeings which then influence the level and mix of services delivered by councils and contribute to the achievements of community outcomes" (Reid, 2008, Abstract). Furthermore, the psychological and pedagogical value of interventions that assist young people to envisage positive futures has been highlighted in various Australian studies (Eckersley, Cahill, Wierenga, \& Wyn, 2007; Eckersley, Wierenga, \& Wyn, 2006; Gidley, 2001; Gidley \& Inayatullah, 2002; Stewart, 2002).

Hope interventions: The interventions that relate to young people's views and visions of their futures are closely connected with interventions that are aimed at facilitating hope and also those aimed at increasing empowerment (Gidley, 2004, 2005). Paulo Freire's pedagogical theories and practices of working with oppressed people in Latin America can be aptly utilised to facilitate social inclusion through creating pedagogies of hope rather than hopelessness (Freire, 1970, 1995). A Brisbane intervention, Sisters Inside, gives hope to incarcerated women by providing pathways to higher education as a means of rehabilitation (Olsson, 2008, p. 6). 
Cultural festivals: One of the best ways to facilitate the deeper feelings of social inclusion that align to engagement and empowerment (in contrast to having access but still feeling disempowered) is for people to be able to express their own cultural values in ways that they are fully valued and honoured. Cultural festivities are a way of affirming a sense of belonging to a culture. Paul James at RMIT University has initiated a cultural festivals project for indigenous Australians, Globalizing Indigeneity: Indigenous Cultural Festivals and Wellbeing in Australia and the Asia-Pacific.

\section{Towards an Integrated Approach to Quality Higher Education}

An integrative theory of quality in higher education is proposed involving a spectrum of ideologies. The notion of quality in higher education is uncoupled from its default neoliberal connections with global competitiveness, and reconsidered in the light of more collaborative and normative ideologies such as those grounded in social justice and human potential. Technicist interpretations of social inclusion and quality are problematised as being too narrow. Instead, broader interpretations of social inclusion and quality in higher education enable each to embrace the three notions of access, participation and success as representing "degrees of social inclusion." Numerous examples of practical social inclusion interventions across the spectrum are also offered.

Through our innovative braiding together of the concept of quality in higher education with a spectrum of ideologies and degrees of social inclusion we unpack and reconfigure some of the underlying systemic processes. This enables the integration of apparently disparate theories, policies, and practices. Higher education access, participation, success, social inclusion and quality are brought into a new integrative theoretical structure. In our view quality in higher education is synonomous with a broad interpretation of social inclusion in higher education in that both are concerned with equitable access, participatory engagement and empowered success.

\section{Notes}

\footnotetext{
${ }^{1}$ Corresponding Author: Dr Jennifer M. Gidley, Research Fellow, Global Cities Research Institute, RMIT University, Melbourne, 3000, Victoria, Australia. The development of the theoretical framework informing this essay was undertaken by Gidley as part of a literature review on social inclusion in higher education initiated and funded by RMIT Learning Community Partnerships Group and the Global Cities Research Institute. The topic of the 2009 IAU/Palgrave essay prize inspired Gidley to undertake further research to extend the literature review to meet the more global context of the essay. Hampson's editorial assistance helped to refine some aspects of the theory and Wheeler and Bereded-Samuel contributed practical insights from their extensive professional experience in university-community engagement. Contact email: jennifer.gidley@rmit.edu.au

${ }^{2}$ Ernst Boyer proposed four types of scholarship: the scholarship of discovery, the scholarship of integration, the scholarship of application and the scholarship of teaching (Boyer, 1990).

3 "The Bologna Process aims to create a European Higher Education Area by 2010, in which students can choose from a wide and transparent range of high quality courses and benefit from smooth recognition procedures." http://ec.europa.eu/education/policies/educ/bologna/bologna_en.html

${ }^{4}$ The latter ideology is reflected in the title of the recent IAU conference: "Associations, Networks, Alliances etc.: Making Sense of the Emerging Global Higher Education Landscape" 2009 Conference of the International Association of Universities, IAU: For A Worldwide Higher Education Community, Mexico.
} 


\footnotetext{
${ }^{5}$ The National CAMHS Support Service (NCSS) is sponsored by the Department of Health (DH) and Department for Education and Skills (DfES) with the aim of offering additional capacity to support the implementation of a comprehensive Child and Adolescent Mental Health Service (CAMHS). The NCSS is part of the Care Services Improvement Partnership Children, Young People and Families national programme, which is delivered in the regions of England. http://www.csip.org.uk/ cypf/camhs/national-camhs-support-service-ncss.html

${ }^{6}$ Neoliberalism can be differentiated from classic liberalism in its interest in the state enforcement of liberalism-an illiberal manoeuvre.

${ }^{7}$ Access and Success is a five year project to improve the access and successful participation of young people in post compulsory education and training through collaborative research and strategic action in partnership with schools in the western region of Melbourne.

${ }^{8}$ The Access to Success project in the USA was initiated in October 2007 by the National Association of System Heads (NASH) - an association of chief executives of the 52 college and university systems of public higher education in the United States and supported in part by grants from Lumina Foundation for Education and the Bill \& Melinda Gates Foundation. http://www2.edtrust.org/EdTrust/Press+Room/AccessToSuccessLaunch.htm
}

\section{References}

Allan, J. (2003) 'Editorial: Social inclusion,' Policy Futures in Education 1(4): 622-625.

Bassett, C. (2005) Wisdom in three acts: Using transformative learning to teach for wisdom [Electronic version]. Paper presented at the Sixth International Transformative Learning Conference; 6-8 October, 2005; East Lansing, Michigan. Retrieved February 22, 2008 http://www.wisdominst.org/EmergentWisdomBassett_spr05.pdf

Bexley, E., Marginson, S., \& Wheelahan, L. (2007) 'Social capital in theory and practice: The contribution of Victorian tertiary education in the 'new economy' disciplines of business $\begin{array}{lllll}\text { studies } \quad \text { and } & \text { IT'. }\end{array}$ http://www.cshe.unimelb.edu.au/pdfs/SocialCapitalNov2007.pdf

Boyer, E. L. (1990) Scholarship reconsidered: Priorities of the professoriate. Princeton, New Jersey: Carnegie Foundation for the Advancement of Teaching.

Bradley, D., Noonan, P., Nugent, H., \& Scales, B. (2008) Review of Australian higher education. Canberra, ACT: Department of Education, Employment, and Workplace Relations, Australian Government.

Broadbent, R., \& Whitehead, F. (2008) The Network Partnership Model: A cross-sectoral approach to youth mentoring and community building. Paper presented at the Partnerships for Social Inclusion Conference; 15-16 October 2008; Centre for Public Policy, Melbourne, Australia.

Burton-Jones, A. (2003) 'Knowledge Capitalism: The new learning economy.' Policy Futures in Education 1: (143-159).

Callaghan, L., \& Moser, L. (2008) Giving Indigenous Victorians a voice: Victoria's representative arrangements for Indigenous Victorians - pathways to social, economic and civic inclusion. Paper presented at the Partnerships for Social Inclusion Conference; 15-16 October 2008; Centre for Public Policy, Melbourne, Australia.

Cherednichenko, B., \& Williams, J. (2007) Growing Educational Capacity through a Collaborative Education Initiative. Paper presented at the Australian Association for Research in Education Conference; 25-29 November 2007; Freemantle, Perth, Australia.

Commons, M. L., \& Richards, F., A. (2002) 'Organizing Components into Combination: How Stage Transition Works.' Journal of Adult Development 9(3): 159-177. 
Cook-Greuter, S. R. (2000) 'Mature Ego Development: A Gateway to Ego Transcendence.' Journal of Adult Development 7(4): 227-240.

Deem, R., Mok, K. H., \& Lucas, L. (2008) 'Transforming Higher Education in Whose Image? Exploring the Concept of the 'World-Class' University in Europe and Asia.' Higher Education Policy 21(1): 83-97.

Delors, J. (1996) Learning: The treasure within. Report to UNESCO of the International Commission on Education for the Twenty-first Century. Paris: UNESCO.

Duff, A. R. (2003). 'Inclusion, exclusion and the criminal law.' Policy Futures in Education 1(4): 699-715.

Eckersley, R., Cahill, H., Wierenga, A., \& Wyn, J. (eds.) (2007) Generations in Dialogue about the Future: The Hopes and Fears of Young Australians. Melbourne, VIC: Australian Youth Research Centre and Australia 21.

Eckersley, R., Wierenga, A., \& Wyn, J. (2006) Flashpoints and Signposts: Pathways to Success and Wellbeing for Australia's Young People: Australian Youth Research Centre, University of Melbourne.

Egan, L. A., Butcher, J., \& Ralph, K. (2008) Hope as a basis for understanding the benefits and possibilities of community engagement. Paper presented at the Engaging for a Sustainable Future: Australian Universities Community Engagement Alliance National Conference; 9-11 July 2008; Sunshine Coast, Australia.

Eisler, R. (2001) 'Partnership Education in the 21st Century.' Journal of Futures Studies 5(3): 143-156.

Fels, M. (2008) Executive summary cohort analysis SNAP: Schools Network Access Program. Melbourne: RMIT University.

Ferrari, G. (2008) YACVic's submission to the parliamentary inquiry into the geographical diffferences in the rate in which Victorian students participate in higher education. Melbourne: Youth Affairs Council of Victoria.

Freire, P. (1970) Pedagogy of the Oppressed. New York: Herder and Herder.

Freire, P. (1995) Pedagogy of hope: Reliving pedagogy of the oppressed. New York: Continuum International Publishing Group.

Gangadean, A. (2006) 'A Planetary Crisis of Consciousness: From Ego-based Cultures to a Sustainable Global World.' Kosmos: An Integral Approach to Global Awakening V: 3739.

Gidley, J. (2001) 'An Intervention Targeting Hopelessness in Adolescents by Promoting Positive Future Images.' Australian Journal of Guidance and Counselling 11(1): 51-64.

Gidley, J. (2004) Imagination and Integration: Empowering Teachers and Children. Paper presented at the Council of Government Schools Organisations (COGSO), 4th Annual Conference; 1-2 May 2004; Darwin, NT, Australia.

Gidley, J. (2005) 'Giving Hope back to our Young People: Creating a New Spiritual Mythology for Western Culture.' Journal of Futures Studies 9(3): 17-30.

Gidley, J., Bateman, D., \& Smith, C. (2004) Futures in Education: Principles, Practice and Potential. Melbourne: Australian Foresight Institute.

Gidley, J., \& Inayatullah, S. (eds.) (2002) Youth Futures: Comparative Research and Transformative Visions. Westport, CT: Praeger.

Gillard, T. H. J. (2008) Introductory remarks. Paper presented at the Education, Employment and Social Inclusion Symposium; 21 August 2008; Melbourne, Australia. 
Giroux, H. A. (2003) 'Selling out higher education.' Policy Futures in Education 1: (179-200).

Grinblat, M., \& Kershaw, A. (2008) Increasing social inclusion through the arts. Paper presented at the Partnerships for Social Inclusion Conference; 15-16 October 2008; Centre for Public Policy, Melbourne, Australia.

Hart, T. (2001) From Information to Transformation: Education for the Evolution of Consciousness. New York: Peter Lang.

Hayes, A., Gray, M., \& Edwards, B. (2008). 'Social inclusion: Origins, concepts and key themes.' Retrieved December 17, 2008, from http:/www.socialinclusion.gov.au/publications.htm

Holland, B., \& Gelman, S. (1998) The State of the "Engaged Campus": What have we learned about building and sustaining university and community partnerships. American Association of Higher Education Bulletin (October): 3-6.

Huisman, J., \& Van der Wende, M. (2004) 'The EU and Bologna: Are supra- and international initiatives threatening domestic agendas?' European Journal of Education 39(3): 349357.

Hunt, P. (2007) 'Rural students suffer.' The Weekly Times, 11 April.

Inayatullah, S., \& Gidley, J. (Eds.). (2000). The University in Transformation: Global Perspectives on the Futures of the University. Westport, Connecticut: Bergin and Garvey.

International Association of Universities. (2008) Equitable access, success and quality in higher education: A policy statement by the International Association of Universities. Utrecht, NL: International Association of Universities.

Jain, M., \& Jain, S. (Eds.). (2003). McEducation for All? Udaipur, India: Shikshantar.

Jain, M., Miller, V., \& Jain, S. (Eds.). (2001) Unfolding Learning Societies: Deepening the Dialogues (Vol. April 2001). Udaipur, Rajasthan, India: The People's Institute for Rethinking education and Development.

James, R. (2008) Participation and equity: A review of the participation in higher education of people from low socioeconomic backgrounds and Indigenous people. Melbourne: Melbourne Graduate School of Education and Universities Australia.

Kelly, E. (2003) 'Integration, Assimilation and Social Inclusion: Questions of faith.' Policy Futures in Education 1(4): 686-698.

Kenway, J., \& Fahey, J. (eds.) (2009) Globalizing the research imagination. Oxon, UK: Routledge.

Kenworthy-U'Ren, A., \& U'Ren, B. (2008) Understanding the "partner" in partnerships: $A$ review of the literature on effective university-community partnering. Paper presented at the Engaging for a Sustainable Future: Australian Universities Community Engagement Alliance National Conference; 9-11 July 2008; Sunshine Coast, Australia.

Kincheloe, J., Steinberg, S., \& Hinchey, P. H. (eds.) (1999) The post-formal reader: Cognition and education, New York: Falmer Press.

Kincheloe, J., Steinberg, S., \& Villaverde, L. E. (1999) Rethinking intelligence: Confronting psychological assumptions about teaching and learning. New York: Routledge.

Langworthy, A. (2008) 'Skills and knowledge for the future: Why universities must engage with their communities.' The Australasian Journal of Community Engagement; 2(2): 57-72.

Lunt, I. (2008) 'Beyond tuition fees? The legacy of Blair's government to higher education.' Oxford Review of Education 34(6): 741-752.

Marginson, S. (2004) 'Competition and Markets in Higher Education: A 'glonacal' analysis.' Policy Futures in Education 2(2): 175-244. 
Marginson, S. (Ed.). (2007) Prospects of Higher Education: Globalization, Market Competition, Public Goods and the Future of the University. Rotterdam, The Netherlands: Sense Publishers.

McGill, S. (2008, October 15-16) "Welcome to the AFL" - Social inclusion through sport. Paper presented at the Partnerships for Social Inclusion Conference; 15-16 October 2008; Centre for Public Policy, Melbourne, Australia.

McInerney, C. (2008) Governance and partnership for social inclusion: Exploring the missing discourse. Paper presented at the Partnerships for Social Inclusion Conference; 15-16 October 2008; Centre for Public Policy, Melbourne, Australia.

McIntyre, J. (2005) Adult learning and Australia's ageing population. Canberra: Adult Learning Australia Inc.

Mohrman, K., Ma, W., \& Baker, D. (2008) 'The Research University in Transition: The Emerging Global Model.' Higher Education Policy 21(1): 5-27.

Montuori, A. (1997) 'Reflections on Transformative Learning: Social Creativity, Academic Discourse and the Improvisation of Inquiry.' ReVision 20(1): 34-37.

Morin, E. (2001) Seven Complex Lessons in Education for the Future. Paris: UNESCO.

Nandy, A. (2000) 'Recovery of Indigenous Knowledge and Dissenting Futures of Universities,' in S. Inayatullah \& J. Gidley (Eds.), The University in Transformation: Global Perspectives on the Futures of the University, Westport, Connecticut: Bergin and Garvey, pp. 115-123.

Newman, P. (2008) The contribution of religion to social inclusion: The role of the Jewish Christian Moslem Association. Paper presented at the Partnerships for Social Inclusion Conference; 15-16 October 2008; Centre for Public Policy, Melbourne, Australia.

Nunan, T., George, R., \& McCausland, H. (2000) 'Inclusive education in universities: Why it is important and how it might be achieved.' International Journal of Inclusive Education 4(1): 63-88.

Nunan, T., George, R., \& McCausland, H. (2005) 'Inclusive education in universities: Why it is important and how it might be achieved.' In K. J. Topping \& S. Maloney (Eds.), The RoutledgeFalmer Reader in Inclusive Education. Oxford, UK: Routledge, pp. 250-260.

Olsson, K. (2008) 'Social inclusion: What would a truly inclusive society look like?' Red, 4-9.

Puuka, J., \& Marmelojo, F. (2008). 'Higher Education Institutions and Regional Mission: Lessons Learnt from the OECD Review Project.' Higher Education Policy 21(2): 217245.

Rasmussen, M. L. (2003) 'Queer Trepidations and the art of inclusion.' Melbourne Studies in Education 44(1): 87-107.

Reid, M. (2008) Planning the future: New Zealand local governments, communities and Long Term Council Community Plans. Paper presented at the Partnerships for Social Inclusion Conference; 15-16 October 2008; Centre for Public Policy, Melbourne, Australia.

Rix, P. (2003) 'Anything is Possible': The arts and social inclusion.' Policy Futures in Education 1(4): 716-730.

Robbie, K. (2008) Working collaboratively with social enterprises: Lessons learned from the United Kingdom. Paper presented at the Partnerships for Social Inclusion Conference: 1516 October 2008; Centre for Public Policy, Melbourne, Australia.

Sinnott, J. D. (1998) The Development of Logic in Adulthood: Postformal Thought and its Applications. New York: Springer. 
Skelton, A. (1999) 'An inclusive higher education? Gay and bisexual male teachers and the cultural politics of sexuality.' International Journal of Inclusive Education 3(3): 239-255.

Steger, M. B. (2005) Globalism: Market ideology meets terrorism (2nd edition). Lanham, Maryland: Rowman and Littlefield Publishers, Inc.

Stewart, C. (2002) 'Re-Imagining your Neighbourhood: A Model of Futures Education.' In J. Gidley \& S. Inayatullah (Eds.), Youth Futures: Comparative Research and Transformative Visions, Westport, CT: Praeger, pp. 187-196.

Thompson, A. (2008) Enhancing access: A disability and the arts inclusion initiative. Paper presented at the Partnerships for Social Inclusion Conference; 15-16 October 2008; Centre for Public Policy, Melbourne, Australia.

Thompson, B. (2008) Use of the E-word: What exactly is "engagement"? Paper presented at the Engaging for a Sustainable Future: Australian Universities Community Engagement Alliance National Conference; 9-11 July 2008; Sunshine Coast, Australia.

Tonks, D., \& Farr, M. (2003) 'Widening access and participation in UK higher education.' The International Journal of Educational Management 17(1): 26-36.

Universities Australia. (2008) Advancing equity and participation in Australian higher education: Action to address participation and equity levels in higher education of people from low socioeconomic backgrounds and Indigenous people. Canberra, ACT: Universities Australia.

Visser, J. (2000) 'Rethinking Learning: Implications for Policy, Research and Practice.' In M. Jain (Ed.), Unfolding Learning Societies: Challenges and Opportunities. Udaipur, India: Shikshantar.

Welch, A. R., \& Zhen, Z. (2008) 'Higher Education and Global Talent Flows: Brain Drain, Overseas Chinese Intellectuals, and Diasporic Knowledge Networks.' Higher Education Policy 21(4): 519-537. 